\title{
Aktivitas Antibakteri Kombinasi Minyak Atsiri Daun Kemangi (Ocimum Basilicum L.) dan Daun Jeruk Purut (Citrus Hystrix D.C.) terhadap Escherichia Coli ATCC 25922
}

\author{
Antibacterial Activity of Essential Oil of Basil Leaves (Ocimum Basilicum L.) And \\ Kaffir Lime Leaves (Citrus Hystrix D.C) Combination Against \\ Escherichia Coli ATCC 25922
}

\author{
Fitri Jati Rukmana ${ }^{1}$, Reslely Harjanti ${ }^{1 *}$, D. Andang Arif Wibawa ${ }^{2}$ \\ ${ }^{1}$ Fakultas Farmasi, Universitas Setia Budi Surakarta \\ ${ }^{2}$ Fakultas Ilmu Kesehatan, Universitas Setia Budi Surakarta \\ Jl. Let. Jend. Sutoyo, Mojosongo, Surakarta, 57127, Jawa Tengah, Indonesia \\ *Corresponding Author: reslely.nindy@gmail.com
}

Received: Agustus 23, 2019; Revise: October 21., 2019; Accepted: December 20, 2019

DOI : https://doi.org/10.31001/biomedika.v12i2.611

\begin{abstract}
ABSTRAK
Minyak atsiri kemangi mengandung komponen senyawa linalool yang tergolong turunan terpenoid yang mempunyai efek antibakteri dan minyak atsiri jeruk purut mengandung senyawa citronella yang dapat menghambat pertumbuhan berbagai jenis bakteri. Penelitian ini bertujuan untuk mengetahui aktivitas antibakteri minyak atsiri daun kemangi, daun jeruk purut dan kombinasi dari keduanya terhadap Escherichia coli ATCC 25922. Metode uji aktivitas antibakteri yang digunakan dalam penelitian ini adalah metode difusi. Konsentrasi sampel uji adalah 2\% dan 4\% dengan perbandingan kombinasi minyak atsiri yaitu 1:1;1:2;2:1. Data hasil penelitian kemudian dianalisis secara Analisis of Varians (ANOVA) dua arah. Hasil penelitian menunjukkan minyak atsiri kombinasi dari daun kemangi (Ocimum basilicum L.) dan daun jeruk purut (Citrus hystrix D.C) memiliki aktivitas antibakteri terhadap Escherichia coli ATCC 25922 dengan konsentrasi 2\% dan 4\% dan variasi kombinasi minyak atsiri dari daun kemangi (Ocimum basilicum L.) dan minyak atsiri daun jeruk purut (Citrus hystrix D.C) yang memiliki daya hambat paling besar terhadap Escherichia coli ATCC 25922 adalah pada kombinasi 1:2 dengan diameter hambat $15,5 \mathrm{~mm}$ pada konsentrasi $4 \%$.
\end{abstract}

Kata kunci: antibakteri; Citrus hystrix D.C; Escherichia coli ATCC 25922; minyak atsiri; Ocimum basilicum L.

\begin{abstract}
Basil essential oil has a component of linalool compounds belonging to terpenoid derivatives which have an antibacterial effect and essential oils of kaffir lime have citronella compounds which can inhibit the growth of various types of bacteria. This study aims to determine the antibacterial activity of essential oils of basil leaves, kaffir lime leaves and the combination of both against Escherichia coli bacteria ATCC 25922. This study has used diffusion methods to test antibacterial activity. The concentration of the sample was $2 \%$ and $4 \%$ with a ratio combination of essential oils were 1:1; $1: 2$; 2:1. Then the research data were analyzed with two way Analysis of Variance (ANOVA). The results showed that essential oils in the combination of basil leaves (Ocimum basilicum L.) and kaffir lime leaves (Citrus hystrix D.C) had antibacterial activity against Escherichia coli ATCC 25922 with concentrations of $2 \%$ and 4\%. Variations of essential oils from basil (Ocimum basilicum L.) leaves and kaffir lime (Citrus hystrix D.C) leaves with a ratio of 1:2 at a concentration of $4 \%$ has the greatest inhibitory potential against Escherichia coli ATCC 25922 with inhibition diameters of $15.5 \mathrm{~mm}$.
\end{abstract}

Key word: antibacterial; Citrus hystrix D.C .; Escherichia coli ATCC 25922, Essential Oils, Ocimum basilicum $L$. 


\section{PENDAHULUAN}

Diare merupakan penyakit endemis di Indonesia dan salah satu penyakit potensional Kejadian Luar Biasa (KLB) yang sering disertai dengan kematian. Pada tahun 2017 penyakit diare terjadi di 34 provinsi dengan jumlah penderita di fasilitas kesehatan sebesar 7.077.299 (Kemenkes RI, 2018).

Diare adalah suatu keadaan di mana frekuensi buang air besar melebihi frekuensi normal dengan konsistensi feses yang encer. Diare ada dua macam yaitu diare spesifik dan non spesifik. Diare spesifik adalah diare yang disebabkan karena bakteri, diare non spesifik disebabkan karena faktor makanan. Diare yang berkepanjangan dapat melemahkan penderitanya karena kehilangan banyak energi dan cairan. Penyebab paling besar pada diare adalah bakteri, salah satu bakteri penyebab diare Salah satunya adalah Escherichia coli. Bakteri tersebut merupakan bagian terbesar flora normal usus besar kuman manusia (Broto, 2006).

Escherichia coli merupakan bakteri Gram negatif berbentuk batang, bersifat anaerob fakultatif (Jawetz et al., 2007). Pada bakteri Escherichia coli terdapat beberapa galur yang patogen dan tidak patogen. Escherichia coli yang tidak patogen dalam jumlah normal ditemukan dalam usus besar manusia. Escherichia coli yang patogen dapat menyebabkan diare yang berat pada semua usia melalui endotoksin yang dihasilkan (BSN, 2009).

Tanaman kemangi (Ocimum basilicum L.) adalah tanaman obat yang memiliki banyak manfaat. Kemangi memiliki senyawa aktif seperti minyak atsiri, alkaloid, saponin, flavonoid, triterpenoid, steroid, tanin dan fenol. Beberapa kandungan kimia tersebut dapat menghambat pertumbuhan bakteri Escherichia coli seperti senyawa alkaloid, minyak atsiri dan fenol. Sifat dari penghambatan ini disebut sebagai bakteriostatik atau bakteriosida (Hadipoentyanti dan Wahyuni, 2008; Oktalia, 2009).

Jeruk purut (Citrus hystrix D.C) adalah tanaman yang banyak dijumpai dan mudah dijangkau oleh masyarakat. Tanaman ini berasal dari genus Citrus merupakan tanaman penghasil minyak atsiri. Tumbuhan ini merupakan tumbuhan perdu yang biasanya dimanfaatkan buah dan daunnya sebagai bumbu penyedap masakan. Jeruk purut di dalam perdagangan internasional dikenal sebagai kaffir lime (Miftahendrawati, 2014)

Minyak atsiri adalah minyak eteris yang merupakan ekstrak alami dari berbagai jenis tumbuhan (Gunawan, 2009). Minyak atsiri dalam genus Ocimum L. mengandung senyawa eugenol, osimen, pinen, linalool, sineol, geraniol, metil kavikol, metil sinamat, sitral, kamfor, timol, benzyl, sitronella, lineon, dan lain sebagainya (Martono et al., 2004). Telah banyak dilakukan penelitian tentang potensi minyak atsiri tumbuhan sebagai antibakteri (Ramesh \& Satakopan 2010).

Pada penelitian sebelumnya dilaporkan bahwa jeruk purut memiliki efek farmakologis sebagai antibakteri, antiseptik dan antioksidan. Senyawa yang yang berperan sebagai antibakteri adalah minyak atsiri, alkaloid, flavonoid, 
dan tanin (Yuliani et al., 2011). Minyak atsiri dalam daun jeruk purut mempunyai potensi sebagai antibakteri pada Klebsiella pneumonia (Jamaludin et al., 2017). Hasil uji dari minyak atsiri daun jeruk purut untuk uji aktivitas antibakteri terhadap Escherichia coli dengan nilai Konsentrasi Bunuh Minimun (KBM) yaitu pada konsentrasi 0,25\% (Maryati et al. 2007).

Minyak atsiri daun kemangi juga dilaporkan mempunyai potensi sebagai antibakteri terhadap Staphylococcus aureus dan Pseudomonas aeruginosa (Silva et al., 2015). Taechowisan et al. (2018) melaporkan bahwa minyak atsiri linalool dan cineole dalam daun kemangi mempunyai potensi antibakteri terhadap Staphylococcus aureus.

Pada penelitian ini memanfaatkan kombinasi penggunaan minyak atsiri daun jeruk purut dan kemangi. Penggunaan kombinasi dapat mengatasi toleransi bakteri, mencegah resistensi, mengurangi toksisitas, dan dapat mencegah inaktivasi oleh enzim (Jawetz et al., 2007). Penelitian terkait penggunaan minyak atsiri daun kemangi (Ocimum basilicum L.) dan daun jeruk purut (Citrus hystrix D.C) secara kombinasi diharapkan dapat memberikan manfaat sebagai efek antibakteri yang lebih optimal dari pada bentuk tunggal minyak atsiri masing-masing tersebut khususnya terhadap Escherichia coli.

\section{METODE PENELITIAN}

\section{Alat dan Bahan}

Alat yang digunakan: jarum ose tangkai panjang, cawan petri steril, inkubator, cakram ukuran $6 \mathrm{~mm}$, autovortex mixer, inkas, autoklaf, oven, neraca analitik, refraktometer abbe 2WAJ dan Shimadzu GCMS-QP2010S

(Shimadzu

Corporation, Kyoto, Japan) dengan Capillary Column Model Number: Agilent 19091S-433 HP-5MS $5 \%$ Phenyl Methyl Siloxane (diameter dalam $250 \mu \mathrm{m}$, panjang $30 \mathrm{~m}$, dan ketebalan film $0.25 \mu \mathrm{m})$ dan detektor yang digunakan FID.

Bahan yang digunakan: $\mathrm{Na}$ sulfat anhidrat, Tween $801 \%$, cakram disk antibiotik, Mueler Hilnton Agar (MHA), Endo Agar (EA), Brain Heart Infusion (BHI), bakteri Escherichia coli ATCC 25922.

\section{Prosedur Penelitian}

Tahap pertama penelitian adalah determinasi terhadap tanaman yang diteliti untuk memastikan bahwa tanaman yang digunakan benar kemangi dan jeruk purut. Selanjutnya diambil bagian tanaman yaitu daun kemudian dicuci bersih dan dipotong-potong. Setelah itu dilakukan proses ekstraksi minyak atsiri dengan cara distilasi uap dan air. Potongan-potongan kecil daun tersebut dimasukkan ke atas angsang dandang destilasi yang sudah berisi air yang dihubungkan dengan kondensor yang berlubang dengan penampung destilat. Distilat yang diperoleh dihitung rendemennya terhadap bahan baku awal dan diperiksa berat jenis dan indeks biasnya. Selain itu diidentifikasi sebagai golongan senyawa minyak atsiri dengan $G C-M S$.

Selanjutnya sampel minyak atsiri yang diperoleh siap untuk diuji aktivitas antibakterinya. Pembuatan sampel uji antibakteri dilakukan dengan membuat 
seri konsentrasi minyak atsiri $2 \%$ dan 4\%. Sampel minyak atsiri daun kemangi dan daun jeruk purut dibuat suspensi dengan penambahan tween 80 konsentrasi $1 \%$. Sampel tunggal minyak atsiri daun kemangi dan minyak atsiri daun jeruk purut kemudian kombinasi dengan perbandingan 1:1, 1:2, 2:1. Dilanjutkan dengan pengujian aktivitas antibakteri dengan metode difusi.

\section{HASIL DAN PEMBAHASAN}

Hasil determinasi menunjukkan bahwa tanaman yang digunakan untuk penelitian adalah benar-benar kemangi (Ocimum basilicum L.) dan jeruk purut (Citrus hystrix D.C). Hasil distilasi minyak atsiri diperoleh rendemen minyak atsiri daun kemangi adalah $0,125 \% \mathrm{v} / \mathrm{b}$ dan daun jeruk purut $0,633 \%$ $\mathrm{v} / \mathrm{b}$.

Berat jenis minyak atsiri kemangi adalah 0,9198 dan jeruk purut 0,8643. Hasil tersebut sudah sesuai dengan pustaka di mana berat jenis minyak atsiri kemangi pada suhu $20^{\circ} \mathrm{C}$ adalah 0,910 0,950 dan jeruk purut 0,8223-0,8699. Indeks bias minyak atsiri daun kemangi yang diperoleh sebesar 1,484 menunjukan hasil indeks bias yang diteliti sesuai dengan pustaka pada minyak atsiri kemangi yaitu 1,426 1,506. Indeks bias minyak atsiri daun jeruk purut diperoleh 1,455 yang menunjukkan hasil indeks bias yang diteliti mendekati dengan pustaka pada minyak daun jeruk purut yaitu 1,4661,516 di mana pengujian indeks bias ini menggunkan alat refraktometer .

Identifikasi yang lain terhadap minyak atsiri dilakukan secara visual yaitu uji noda di kertas saring sampel minyak atsiri daun kemangi dan minyak atsiri daun jeruk purut masing-masing menunjukkan hasil tidak meninggalkan noda sesuai dengan pustaka (Gunawan dan Mulyani, 2004). Uji penyebaran minyak atsiri di atas permukaan air menunjukkan hasil minyak atsiri daun kemangi dan minyak atsiri daun jeruk purut yang sudah ditambahkan lake ponceau 4R dapat menyebar pada permukaan air.

Karakterisasi komponen senyawa penyusun minyak atsiri dilakukan dengan Gas Chromatography yang ditandem dengan Mass Spectrometry (GC-MS). Kondisi GC: suhu awal $60{ }^{\circ} \mathrm{C}$ dinaikkan sampai $250{ }^{\circ} \mathrm{C}\left(4{ }^{\circ} \mathrm{C} /\right.$ menit $)$ kemudian pada suhu $250{ }^{\circ} \mathrm{C}$ dipertahankan selama 20 menit, gas pembawa Helium dengan kecepatan aliran $20 \mathrm{ml} / \mathrm{min}$. Senyawa diidentifikasi dengan membandingkan retention index dan membandingkan mass spectra dengan yang ada di database wiley library dan NIST library. Hasil analisis masing-masing komponen senyawa utama minyak atsiri daun kemangi dan daun jeruk purut dapat dilihat pada Tabel 1 dan Tabel 2. 
Tabel 1. Hasil identifikasi komponen senyawa minyak atsiri daun kemangi

\begin{tabular}{llllll}
\hline No & $\begin{array}{c}\text { Waktu } \\
\text { retensi } \\
\text { (menit) }\end{array}$ & $\begin{array}{c}\text { \% Luas } \\
\text { area }\end{array}$ & $\mathbf{B M}$ & \multicolumn{1}{c}{ Nama senyawa } & \% Similarity \\
\hline $\mathbf{1}$ & 7.338 & 35.71 & 154 & Linalool & 96 \\
\hline $\mathbf{2}$ & 8.067 & 7.37 & 152 & $\begin{array}{l}\text { TRANS-CARAN, 4,5- } \\
\text { EPOXI- }\end{array}$ & 88 \\
$\mathbf{3}$ & 8.284 & 10.63 & 152 & $\begin{array}{l}\text { TRANS-CARAN, 4,5- } \\
\text { EPOXI- }\end{array}$ & 90 \\
$\mathbf{4}$ & 10.321 & 1.49 & 172 & $\begin{array}{l}\text { CIS 3 HEXENYL } \\
\text { LACTATE }\end{array}$ & 93 \\
$\mathbf{5}$ & 10.545 & 1.59 & 150 & $\begin{array}{l}\text { 3,5-Heptadienal,n2- } \\
\text { ethylidene-6-methyl-(cas) }\end{array}$ & 85 \\
$\mathbf{6}$ & 10.827 & 12.24 & 204 & $\begin{array}{l}\text { Trans-Caryophyllene } \\
\text { alpha.-Bergamotene }\end{array}$ & 95 \\
$\mathbf{7}$ & 10.893 & 5.43 & 204 & $\begin{array}{l}\text { alpha.-Humulene } \\
\text { GERMACRENE-D }\end{array}$ \\
$\mathbf{8}$ & 11.068 & 3.75 & 204 & 90 \\
$\mathbf{1 0}$ & 11.260 & 9.20 & 204 & $\begin{array}{l}\text { GEMA.-Humulene } \\
\text {.alpha.-Hume }\end{array}$ \\
\hline
\end{tabular}

Tabel 2. Hasil identifikasi komponen senyawa minyak atsiri daun jeruk purut

\begin{tabular}{llllll}
\hline No & $\begin{array}{c}\text { Waktu } \\
\text { retensi } \\
\text { (menit) }\end{array}$ & $\begin{array}{c}\text { \% } \\
\text { Luas } \\
\text { area }\end{array}$ & BM & \multicolumn{1}{c}{ Nama senyawa } & \% Similarity \\
\hline $\mathbf{1}$ & 7.953 & 34.23 & 154 & CITRONELLA & 95 \\
\hline $\mathbf{2}$ & 8.080 & 9.86 & 154 & CITRONELLA & 97 \\
\hline $\mathbf{3}$ & 8.974 & 21.95 & 156 & .beta.-Citronellol & 97 \\
\hline $\mathbf{4}$ & 10.081 & 17.59 & 198 & Citronellyl acetate & 94 \\
\hline $\mathbf{5}$ & 10.280 & 4.37 & 196 & NERYL ACETATE & 96 \\
\hline $\mathbf{6}$ & 11.650 & 2.10 & 222 & Elemol & 93 \\
\hline $\mathbf{7}$ & 11.696 & 1.64 & 222 & Nerolidol & 86 \\
\hline $\mathbf{8}$ & 12.476 & 2.15 & 218 & $\begin{array}{l}\text { LONGIVERBENON } \\
\text { (VULGARON B) }\end{array}$ \\
\hline $\mathbf{9}$ & 12.555 & 0.89 & 218 & $\begin{array}{l}\text { LONGIVERBENON } \\
\text { (VULGARON B) }\end{array}$ & 85 \\
\hline $\mathbf{1 0}$ & 12.629 & 5.22 & 218 & $\begin{array}{l}\text { 2(3H)-NAPHTHALENONE, } \\
\text { 4,4A,5,6,7,8-HEXAHYDRO- }\end{array}$ & 86 \\
\hline
\end{tabular}

Hasil analisis minyak atsiri daun kemangi dan jeruk purut menggunakan GC menunjukkan masing-masing mengandung 10 senyawa. Identifikasi komponen kimia hasil kromatogram GCMS dilakukan dengan membandingkan pola fragmentasi spektrum massa yang ada pada pustaka. Komponen senyawa utama yang terdeteksi pada kromatogram minyak atsiri daun kemangi adalah linalool dengan persentase $35,71 \%$ dan pada minyak 
atsiri daun jeruk purut yaitu citronella dengan persentase $34,23 \%$. Berdasarkan data persen kemiripan senyawa dengan pustaka dapat diketahui bahwa senyawasenyawa yang mempunyai kemiripan terbesar yang terkandung dalam minyak atsiri daun kemangi adalah Linalool dan minyak atsiri daun jeruk purut adalah Citronella.

Metode pengujian aktivitas antibakteri minyak atsiri daun kemangi dan daun jeruk purut dilakukan secara difusi. Metode difusi dilakukan terhadap kombinasi minyak atsiri daun kemangi dan daun jeruk purut dengan konsentrasi $2 \%$ dan $4 \%$, pada perbandingan $1: 1,1: 2$, 2:1 dan tunggal minyak atsiri daun kemangi dan daun jeruk purut menggunakan cakram disk, dengan kontrol positif ciprofloxacin digunakan untuk daya antibakteri. Hasil dapat dilihat pada Tabel 3.

Tabel 3. Hasil uji difusi pada Escherichia coli ATCC 25922

\begin{tabular}{|c|c|c|c|c|c|}
\hline \multirow[t]{3}{*}{$\begin{array}{c}\text { Sampel } \\
\text { (minyak atsiri) }\end{array}$} & \multirow[t]{3}{*}{ Konsentrasi } & \multirow{2}{*}{\multicolumn{3}{|c|}{$\begin{array}{c}\begin{array}{c}\text { Diameter hambat } \\
(\mathbf{m m})\end{array} \\
\text { Replikasi }\end{array}$}} & \multirow[t]{3}{*}{$\begin{array}{c}\text { Rata-rata }(\mathrm{mm}) \\
\pm \mathrm{SD}\end{array}$} \\
\hline & & & & & \\
\hline & & 1 & 2 & 3 & \\
\hline Daun kemangi & $2 \%$ & 11,5 & 8,4 & 12,6 & $10,83 \pm 1,778264$ \\
\hline $\begin{array}{c}\text { Daun jeruk purut } \\
\text { tunggal }\end{array}$ & $2 \%$ & 6 & 7 & 7,5 & $6,83 \pm 0,62361$ \\
\hline $1: 1$ & $2 \%$ & 15,25 & 11 & 8,75 & $11,67 \pm 2,69516$ \\
\hline $1: 2$ & $2 \%$ & 15 & 10,75 & 9,5 & $11,75 \pm 2,354074$ \\
\hline $2: 1$ & $2 \%$ & 16 & 8,25 & 9,75 & $11,33 \pm 3,356172$ \\
\hline Kontrol + & & 23,75 & 27,5 & 26,5 & $25,92 \pm 1,585525$ \\
\hline Kontrol - & & 0 & 0 & 0 & 0 \\
\hline Daun kemangi & $4 \%$ & 11,5 & 15,25 & 13 & $13,25 \pm 1,541104$ \\
\hline Daun jeruk purut & $4 \%$ & 7 & 12 & 6,75 & $8,58 \pm 2,418103$ \\
\hline $1: 1$ & $4 \%$ & 19,5 & 12 & 12 & $14,5 \pm 3,535534$ \\
\hline $1: 2$ & $4 \%$ & 20 & 12,25 & 14,25 & $15,5 \pm 2,875$ \\
\hline $2: 1$ & $4 \%$ & 17 & 12,5 & 13,25 & $14,25 \pm 1,968502$ \\
\hline Kontrol + & & 26 & 26,5 & 29 & $27,167 \pm 1,312335$ \\
\hline Kontrol - & & 0 & 0 & 0 & 0 \\
\hline
\end{tabular}




\section{Keterangan :}

1:1 : 1 bagian minyak atsiri daun jeruk purut dan 1 bagian minyak atsiri daun kemangi $1: 2: 1$ bagian minyak atsiri daun jeruk purut dan 2 bagian minyak atsiri daun kemangi $2: 1: 2$ bagian minyak atsiri daun jeruk purut dan 1 bagian minyak atsiri daun kemangi kontrol + : ciprofloxacin kontrol - : cakram yang berisi aquadest steril.

Hasil uji difusi menunjukkan bahwa pada konsentrasi $2 \%$ dan $4 \%$ tunggal maupun kombinasi $(1: 1 ; 1: 2 ; 2: 1)$ masing-masing memiliki potensi daya hambat terhadap bakteri Escherichia coli ATCC 25922 jika dibandingkan dengan control positif ciprofloxacin. Daya hambat paling besar adalah pada minyak atsiri kombinasi dengan perbandingan 1:2 dengan konsentrasi $4 \%$ yang diameter daya hambatnya adalah 15,5 $\mathrm{mm}$. Daya hambat minyak atsiri kombinasi mempunyai perbedaan yang signifikan dari minyak atsiri tunggal daun kemangi, tunggal daun jeruk purut, kontrol positif, dan kombinasi $(1: 1 ; 1: 2 ; 2: 1)$. Hal ini menunjukkan bahwa penggunaan kombinasi minyak atsiri dapat meningkatkan potensi antibakteri jika dibandingkan dengan sediaan tunggal masing-masing. Penggunaan kombinasi senyawa tersebut dapat menghasilkan efek sinergisme yang memperkuat potensi masing-masing sebagai antibakteri Analisis data menunjukkan hasil uji homogenitas dengan diameter hambat minyak atsiri signifikan 0,138 yang berarti $0,138>0,05$ hasil test homogenitas signifikan.

Pada uji ANOVA dua jalan dengan demikian dapat disimpulkan bahwa adanya perbedaan daya hambat yang nyata pada sampel tunggal minyak atsiri kemangi dengan hasil tunggal minyak atsiri daun jeruk purut. Daya hambat kontrol positif mempunyai perbedaan yang signifikan dari minyak atsiri tunggal daun kemangi, tunggal daun jeruk dan kombinasi $(1: 1,1: 2,2: 1)$ pada uji Two Way Anova. Berdasarkan hasil ratarata diameter daya hambat pada kombinasi yang lebih besar yaitu pada kombinasi dengan perbandingan 1:2 dibandingkan dengan kombinasi 1:1; 1:2. Daya hambat kombinasi minyak atsiri daun kemangi dan minyak atsiri daun jeruk purut terhadap Escherichia coli ATCC 25922 pada konsentrasi $2 \%$ dan $4 \%$ masing-masing dilakukan 3 kali replikasi ditunjukkan pada Gambar 1.

Minyak atsiri mempengaruhi langsung selaput sel mikroorganisme patogen dengan menyebabkan peningkatan permeabilitas dan kebocoran konstituen intraseluler vital, dan akhirnya mengganggu respirasi sel dan mikroba sistem enzim (Akhtar et al., 2014). Berdasarkan penelitian ini dapat dijadikan acuan bahwa minyak atsiri yang juga disebut minyak esensial dari kombinasi tanaman obat khususnya daun jeruk purut dan daun kemangi dapat digunakan sebagai zat alami antimikroba alternatif dan juga diharapkan akan memainkan peran besar dalam penemuan obat baru di masa mendatang. 


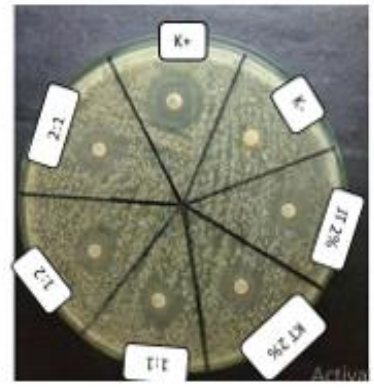

a

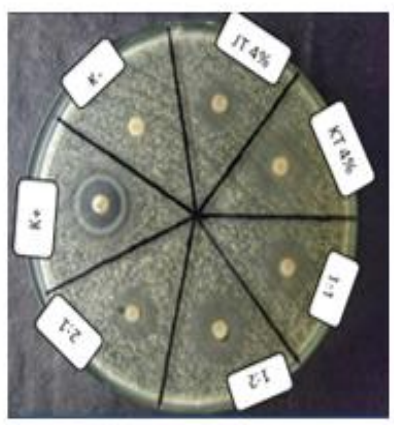

d

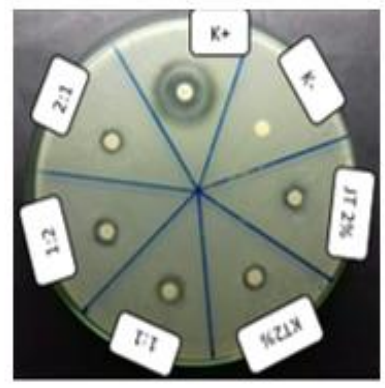

b

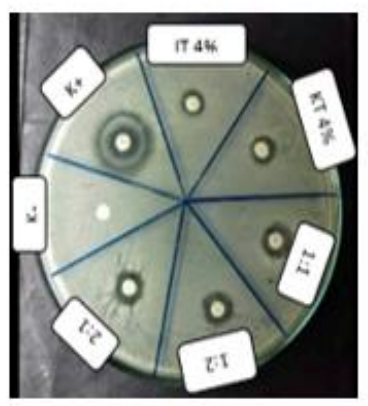

e

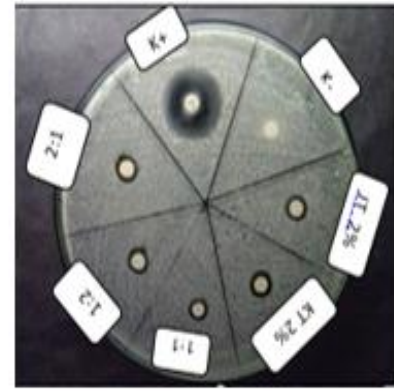

c

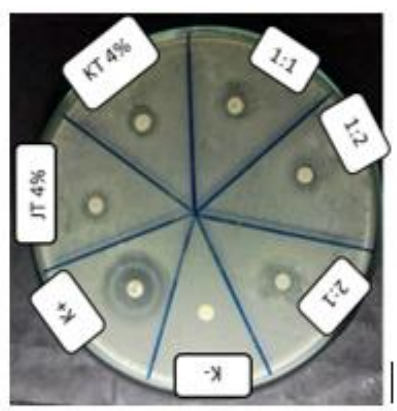

f

Gambar 1. Daya hambat sampel terhadap Escherichia coli ATCC 25922 (a) konsentrasi $2 \%$ replikasi 1; (b) konsentrasi $2 \%$ replikasi 2; (c) konsentrasi $2 \%$ replikasi 3; (d) konsentrasi 4\% replikasi 1; (e) konsentrasi 4\% replikasi 1;

(f) konsentrasi $4 \%$ replikasi 3

\section{KESIMPULAN}

Minyak atsiri kombinasi dari daun kemangi (Ocimum basilicum L.) dan daun jeruk purut (Citrus hystrix D.C) memiliki aktivitas antibakteri terhadap Escherichia coli ATCC 25922 dengan konsentrasi 2\% dan $4 \%$. Variasi kombinasi minyak atsiri dari daun kemangi (Ocimum basilicum L.) dan daun jeruk purut (Citrus hystrix D.C) yang memiliki daya hambat paling besar terhadap Escherichia coli ATCC 25922 adalah pada kombinasi 1:2 dengan diameter hambat $15,5 \mathrm{~mm}$ pada konsentrasi $4 \%$.

\section{DAFTAR PUSTAKA}

Adeola SA, Folorunso, OS, \& Amisu KO. (2012). Antimicrobial Activity of Ocimum basilicum and its Inhibition on the Characterized and Partially Purified Extracelullar Protease of Salmonella Typhimurium. Research Journal of Biology 2 (5): 138-144.

Akthar MS, Degaga B, Azam T. 2014. Antimicrobial activity of essential oils extracted from medicinal plants against the pathogenic microorganisms: A review. Biological Sciences and Pharmaceutical Research. Vol.2 (1), 001007.

Badan Standarisasi Nasional. (2009). Batas Maksimum Cemaran Mikroba dalam pangan. SNI:7388.

Bilal A, Jahan N, Ahmed A, Bilal SN, Habib S \& Hajra S. (2012). Phytochemical and pharmacoloigical Studies on Ocimum 
basilicum Linn- A Review. IJCRR 4 (23): 73-83.

Bonang G, Koeswardono ES. (2004). Mikrobiologi Kedokteran untuk Laboratorium dan Klinik. Jakarta: Bagian Mikrobiologi Fakultas Kedokteran Universitas Indonesia

Dhulgande, G., A.R.Birari \& D.A. Dhale. (2010). Preliminary Screening ofAntibacterial and Phytochemical Studies of Ocimum americanum Linn. Journal of Ecobiotechnology, 2 (8) : 11-13.

Gunawan Hadipoenyanti E \& Wahyuni. S. (2008). Keragaman Selasih (Ocimum Spp.) Berdasarkan Karakter Morfologi, Produksi dan Mutu Herba. Bandung: ITB. Hal 141-148.

Gunawan D, Mulyani S. (2004). Ilmu Obat Alam (Farmakognosi). Jilid 1. Jakarta: Penebar Swadaya.

Hadipoentyanti, Endang.,\& Wahyuni, Sri. (2008). Keragaman Selasih (Ocimum spp.) Berdasarkan Karakter Morfologi roduksi dan Mutu Herbal, Jurnal Litri, Vol(4)

Jamaluddin N, Pulungan MH, Warsito. (2017). Uji Aktivitas Antibakteri Minyak Atsiri Jeruk Purut (Citrus hystrix DC) terhadap Klebsiella pneumoniae ATCC. Industria: Jurnal Teknologi dan Manajemen Agroindustri Vol 6 No 2: 61-66

Jawetz, Melnick, J.L., and Adelberg, E.A. (2007). Medical Microbiologi $24^{\text {th }}$ edition. USA: Mc-Graw Hill companies.

[Kemenkes RI] Kementerian Kesehatan Republik Indonesia. (2017). Profil Kesehatan Indonesia Tahun 2017. Jakarta: Kementerian Kesehatan Re publik Indonesia.

Mariyati, Ratna SF dan Triastuti R. (2007). Uji aktivitas Antibakteri Minyak Atsiri Daun Kemangi (Ocimum basilicum L.)
Terhadap Staphylococcus aureus Dan Escherichia Coli. Jurnal Penelitian Sains \& Teknologi 8 .

Martono BE, Hadipoentyanti dan L Udarno. (2004). Plasma Nuftah Insektisida Nabati. Perkembangan. Teknologi TRO XVI.

Maruti J, Dhanavade, Chidamber B, Jalkute, Jai S, Ghosh and Kailash D, Sonawane. (2011). Study Antimicrobial Activity of Lemon (Citrus lemon L.) Peel Extract. British Journal of Pharmacology and Toxicology 2(3): 119-122.

Oktalia. (2009). Kapita Selekta Dispending I. Yogyakarta: UGM Press. Halaman 27.

Ramesh B \& Satakopan V N. 2010. In Vitro Antioxidant Activities Ocimum Species: Ocimum basilicum and Ocimum Sanctum, Journal of Cell and Tissue Research 10. 1: 2145-2150.

Silva VA, Sousa, JP, Guerra FQS , Pessôa HLF, Freitas AFR, Alves LBN, Lima EO. (2015). Antibacterial Activity of Ocimum basilicum Essential Oil and Linalool on Bacterial Isolates of Clinical Importance. International Journal of Pharmacognosy and Phytochemical Research; 7(6); 10661071.

Taechowisan T, Jantiya J, Mungchukeatsakul N, and Phutdhawong WS. (2018). Major Compounds from Ocimum basilicum L. and their Antimicrobial Activity against Methicillin-Resistant Staphylococcus aureus. Biomed J Sci \& Tech Res 3(3). BJSTR.MS.ID.000910.

Yuliani, R., Peni, I., dan Septi, S. R. (2011). Aktivitas Antibakteri Minyak Atsiri Daun Jeruk Purut (Citrus hystrix) terhadap Staphylococcus aureus dan Escherichia coli. Journal Pharmacon 12(2): 50 - 4. 